\title{
ELF5 in epithelial ovarian carcinoma tissues and biological behavior in ovarian carcinoma cells
}

\author{
HONGCHAO YAN ${ }^{1}$, LINGLIN QIU ${ }^{1}$, XIAOLEI XIE ${ }^{1}$, HE YANG $^{1}$, YONGLI LIU ${ }^{2}$, \\ XIAOMAN LIN ${ }^{1}$ and HONGXIANG HUANG ${ }^{1}$ \\ ${ }^{1}$ Department of Obstetrics and Gynecology, The Affiliated Hospital of Xuzhou Medical University, Xuzhou, Jiangsu 221002; \\ ${ }^{2}$ Department of Obstetrics and Gynecology, The First People's Hospital of Xuzhou, Xuzhou, Jiangsu 221000, P.R. China
}

Received August 5, 2016; Accepted January 23, 2017

DOI: 10.3892/or.2017.5418

\begin{abstract}
The expression of E74-like factor 5 (ELF5) in epithelial ovarian carcinoma tissues and its effects on biological behavior in ovarian carcinoma cells were assessed in search for a new approach for gene treatment of epithelial ovarian carcinoma. RT-PCR technology was applied to detect the expression of ELF5 mRNA in epithelial ovarian carcinoma $(n=49)$, borderline ovarian epithelial tumor $(n=19)$, benign ovarian epithelial tumor $(n=31)$ and normal ovarian tissues $(n=40)$. Then, we transfected recombinant plasmid pcDNA3.1-ELF5+EGFP into human ovarian carcinoma SKOV3 cells (recombinant plasmid group) in vitro and screened out stably transfected cells to conduct multiplication culture. Western blot analysis was performed to detect the expression of ELF5 protein in the different groups. Flow cytometry was employed to detect cell apoptosis and cycles. ELF5 mRNA in epithelial ovarian carcinoma and borderline ovarian epithelial tumor tissues were significantly lower $(\mathrm{P}<0.05)$ than those in benign ovarian epithelial tumor and normal ovarian tissues. ELF5 protein expression in the cells of recombinant plasmid group was significantly higher compared with empty plasmid and blank control groups. The capacity of cell reproductive recombinant plasmid group at each time point decreased $(\mathrm{P}<0.05)$. Flow cytometry detection showed that $67.03 \%$ of cells in recombinant plasmid group was blocked in $\mathrm{G}_{0} / \mathrm{G}_{1}$ phase $(\mathrm{P}<0.05)$, compared with empty plasmid group (37.17\%) and blank control group (38.24\%). Apoptotic rate of recombinant plasmid group was significantly lower $(31.4 \pm 1.9 \%$; $\mathrm{P}<0.05)$, compared with that of empty plasmid group $(9.1 \pm 2.2 \%)$ and blank control group $(8.7 \pm 1.5 \%)$, and the differences were statistically significant. In conclusion,
\end{abstract}

Correspondence to: Dr Hongchao Yan, Department of Obstetrics and Gynecology, The Affiliated Hospital of Xuzhou Medical University, 99 Huaihai West Road, Xuzhou, Jiangsu 221002, P.R. China E-mail: 1015058194@qq.com

Key words: E74-like factor 5 gene, epithelial ovarian carcinoma, transfection, SKOV3 cells
ELF5 interfered with cell cycle of human ovarian carcinoma SKOV3 cells and promoted apoptosis of human ovarian carcinoma SKOV3 cells inhibiting their growth and invasive capacity; and thus providing a new approach to gene treatment of ovarian carcinoma.

\section{Introduction}

As one of gynecologic malignant tumors that do harm to women's health, ovarian malignant carcinoma can occur at any age and seriously threaten women's health $(1,2)$. Although there are many types of ovarian malignant carcinoma, epithelial ovarian carcinoma is more common. At present, there is no effective and thorough method to treat epithelial ovarian carcinoma (3). The occurrence of epithelial ovarian carcinoma is a process with many factors and steps and is related to the activation of oncogenes and the inactivation of tumor suppressor genes. Many investigations have been conducted on its pathogenesis on molecular biology level in order to find a specific and effective method to treat ovarian carcinoma $(4,5)$. E74-like factor 5 (ELF5) is a member with epithelial specificity in E-twenty-six (Ets) gene family and is also known as ESE2. ELF5 plays a key role in the process of cell development, differentiation and apoptosis and regulates and controls cell proliferation and the occurrence of tumors $(6,7)$. The relationship between ELF5 and epithelial ovarian carcinoma has not been reported yet. Therefore, the present study applied RT-PCR technology to detect the expression of ELF5 mRNA in epithelial ovarian carcinoma tissues and analyzed its correlation with clinicopathological indexes. We constructed recombinant plasmid pcDNA3.1-ELF5+EGFP containing ELF5, applied gene transfection technology in vivo to transfect eukaryotic expression vector containing ELF5 gene into human ovarian carcinoma SKOV3 cells, and observed its effects on the cell cycle, apoptosis and invasive capacity of ovarian carcinoma SKOV3 cells; and report the effects of this gene on the occurrence and development of epithelial ovarian carcinoma.

\section{Subjects and methods}

Research subjects. The patients signed an informed consent form as required by the Ethics Committee of our hospital. 
Patients who underwent operative treatment in the Department of Obstetrics and Gynecology of the Affiliated Hospital of Xuzhou Medical University from February 2013 to October 2015 were studied, including 49 cases of epithelial ovarian carcinoma, 19 cases of borderline ovarian epithelial tumor, 31 cases of benign ovarian epithelial tumor and 40 cases of normal ovarian tissues. Patients with epithelial ovarian carcinoma had no history of preoperative radiotherapy and chemotherapy, aged from 26 to 73 years and an average of 49.1 years. Pathological types: 32 cases of serous cystadenocarcinoma and 17 cases of mucinous cystadenocarcinoma. Clinical stages: Staging criteria of International Federation of Gynecology and Obstetrics (FIGO) in 2013 (8) was applied and there were 9 cases of phase I, 14 cases of phase II, 23 cases of phase III and 3 cases of phase IV; pathological grading: 20 cases of G1, 17 cases of G2 and 12 cases of G3; 21 cases with lymph node metastases and 28 cases without lymph node metastases; 16 cases with ascites and 33 cases without ascites. After the specimens were excised during the operation, tumor tissues were isolated from primary ovarian lesion immediately and rapidly frozen in liquid nitrogen, and then stored at $-70^{\circ} \mathrm{C}$ until use. The rest of the sample was sent for pathological examination. Normal ovarian tissues were from older patients with uterine fibroids, who required unilateral or bilateral adnexectomy.

Sources of materials. TRIzol reagent was purchased from Gibco (Grand Island, NY, USA), RT-PCR kit was purchased from Promega Corp. (Madison, WI, USA), heat-resistant DNA polymerase and ELF5 gene primer was compounded by Sangon Biotech Co., Ltd. (Shanghai, China). DNA endonuclease, DNA ligase and DNA marker were purchased from Fermentas (Glen Burnie, MD, USA). DNA gel extraction kit and agarose were purchased from Tiangen Biotech (Beijing) Co., Ltd. (Beijing, China). Medium extraction kit was purchased from Axygen Biosciences Co., Ltd. (Hangzhou, China). Absolute ethyl alcohol, isopropanol, glycerol and anhydrous calcium chloride were purchased from Sinopharm Chemical Reagent Co., Ltd. (Beijing, China). Human ovarian carcinoma SKOV3 cells were purchased and stored by the Laboratory of Obstetrics and Gynecology Department of the Affiliated Hospital of Xuzhou Medical University. Methyl thiazolyl tetrazolium (MTT) was the product of Sigma-Aldrich (St. Louis, MO, USA). Liptapfector lipofectin transfection reagent was provided by Beyotime Biotech (Jiangsu, China). Transwell chamber and ELF5 primary antibody (dilution, 1:1,000; cat. no. AM254515) was provided by Chemicon (Temecula, CA, USA). Escherichia coli DH5 $\alpha$ was purchased and stored by the Laboratory of Obstetrics and Gynecology Department of the Affiliated Hospital of Xuzhou Medical University.

\section{Methods}

Tissue RNA was extracted by TRIzol reagent. Reverse transcription reaction was conducted by applying the standard conditions provided by reverse transcription reagent (Promega Corp.), and the obtained cDNA served as PCR reactive template.

Primers were compounded according to reference (9): ELF5 upstream primer, 5'CAAGACTGTCACAGTCATAG3' and downstream primer, 5'GTCAACCCGCTCCAAAA
TTC3'; amplified fragment was $260 \mathrm{bp}$. Serving as the internal reference, $\beta$-actin upstream primer, 5'CGGGAAGCTTGTG ATCAT3' and downstream primer, 5'GGCAGTGATGGCAT GAC3'; amplified fragment was $157 \mathrm{bp}$. The reaction conditions were $94^{\circ} \mathrm{C}$ for $45 \mathrm{sec}, 55^{\circ} \mathrm{C}$ for $60 \mathrm{sec}$ and $72^{\circ} \mathrm{C}$ for $60 \mathrm{sec}$. After 30 cycles, extension was performed at $72^{\circ} \mathrm{C}$ for $10 \mathrm{~min}$.

Detection of PCR products: The fragments amplified by PCR were inspected by $2 \%$ agarose gel electrophoresis and observed under ultraviolet detector; images were taken and records were made: 260 bp amplified bands occurred in patients with the expression of ELF5 gene, while specific amplified bands did not occur in patients with the deletion of ELF5 gene. Chemi Imager 5500 software of automatic electrophoresis gel imaging analyzer was applied to analyze the contents of products of all amplified bands and the relative expression level of ELF5 mRNA was expressed by the ratio of ELF5/ $\beta$-actin content.

Construction and identification of pcDNA3.1-ELF5+EGFP eukaryotic expression vector. Oligo design is used for vector subcloning by adding BamHI, EcoRI and protective base to upstream and downstream primers of target gene. See Fig. 1 for oligo sequences.

The above primers were compounded by Gene Pharma (Shanghai, China). The oligo was dissolved to $50 \mu \mathrm{M}$ and the same volume of oligo was taken and put into a $1.5 \mathrm{ml}$ centrifuge tube, mixed well to prepare the oligo mix used in the first round of PCR reaction. The reaction system was as follows: Oligo mix $6 \mu 1$, 10X Pfu buffer $\left(+\mathrm{Mg}^{2+}\right) 5 \mu \mathrm{l}$, dNTP $1 \mu \mathrm{l}$, oligo-1 $1 \mu \mathrm{l}$, oligo-34 $1 \mu \mathrm{l}, \mathrm{ddH}_{2} \mathrm{O} 36 \mu \mathrm{l}$, Pfu DNA polymerase $0.3 \mu \mathrm{l}$. Cycling conditions: $95^{\circ} \mathrm{C}$ for $3 \mathrm{~min} 1$ cycle, $94^{\circ} \mathrm{C}$ for $30 \mathrm{sec} 30 \mathrm{cycles}, 55^{\circ} \mathrm{C}$ for $30 \mathrm{sec}, 72^{\circ} \mathrm{C}$ for $30 \mathrm{sec}$, $72^{\circ} \mathrm{C} 5$ min 1 cycle. The oligo- 1 and oligo-34 were used for the second round of PCR reaction, with the products of the first PCR reaction serving as template. Reaction conditions remained the same as those of the first round. The first round of PCR obtain non-single band PCR product with the target gene band. With the PCR products of the first round as template, single target gene band was obtained through the second round of PCR. After the completion of PCR reaction, agarose electrophoresis and gel extraction was used to recycle ELF5+EGFP gene fragments.

ELF5+EGFP gene fragments were conducted with enzyme digestion for $2 \mathrm{~h}$ at $37^{\circ} \mathrm{C}$ by $B a m \mathrm{HI}$ and EcoRI and vector pcDNA3.1 was conducted with enzyme digestion for $2 \mathrm{~h}$ at $37^{\circ} \mathrm{C}$ by $B a m \mathrm{HI}$ and EcoRI. ELF5+EGFP gene fragments and vector pcDNA3.1 were recycled by applying DNA gel extraction kit. ELF5+EGFP gene fragments and linear vector were obtained by applying T4 DNA ligase to connect double enzyme digestion at $22^{\circ} \mathrm{C}$ for $2 \mathrm{~h}$. Competent cells were prepared by calcium chloride method and a single colony was selected from the fresh plate cultured at $37^{\circ} \mathrm{C}$ for $16 \mathrm{~h}$ to transfer into a one-liter flask containing $100 \mathrm{ml}$ LB medium, cultured by shaking at $37^{\circ} \mathrm{C}$ for $3 \mathrm{~h}$ (rotary shaker, $300 \mathrm{rpm}$ ). Under aseptic conditions, cells were transferred into a disposable ice-precooling $50 \mathrm{ml}$ polypropylene tube, placed on ice for $10 \mathrm{~min}$ and culture was cooled to $0^{\circ} \mathrm{C}$. Cells were recycled by centrifuging at $1,200 \mathrm{x} \mathrm{g}$ at $4^{\circ} \mathrm{C}$ for $10 \mathrm{~min}$. Culture solution was poured out and the tube was drained for $1 \mathrm{~min}$. The connection products were 


\begin{tabular}{|c|c|}
\hline Y853-1 & GATAGGGATCCGCCACCATGCCA \\
\hline Y853-2 & ACATTACCCTGTGGGAGTGAGGCAGAGATGGCATGGTGGCGGATC \\
\hline Y853-3 & СТСАСТСССАCAGGGTAATGTTGGACTCGGTGACACACAGCACCT \\
\hline Y853-4 & GATCGCAGAAGGATGCATTAGGCAGGAAGGTGCTGTGTGTCACCG \\
\hline Y853-5 & ССTAATGCATCCTTCTGCGATCCCCTGATGTCGTGGACTGATCTG \\
\hline Y853-6 & AGGGTAGTACTCTTCATTGCTGAACAGATCAGTCCACGACATCAG \\
\hline Y853-7 & TCAGCAATGAAGAGTACTACCCTGCCTTTGAGCATCAGACAGCCT \\
\hline Y853-8 & TGGACTGATGTCCAGTATGAGTCACAGGCTGTCTGATGCTCAAAG \\
\hline Y853-9 & АСТСАТАСТGGАСАТСАGTССАСССТGАATACTGGACTAАGСGCС \\
\hline Y853-10 & AGAACTGGAGCСАСТСССАСАСАTGGСGСТTAGTCСАGTATTCAG \\
\hline Y853-11 & GGGAGTGGCTCCAGTTCTGCTGCGACCAGTACAAGTTGGACACCA \\
\hline Y853-12 & TGAAGTTGCAGAAGGAGATGCAATTGGTGTCCAACTTGTACTGGT \\
\hline Y853-13 & GCATCTCCTTCTGCAACTTCAACATCAGTGGCCTGCAGCTGTGCA \\
\hline Y853-14 & TGCCTCGACGAACTCCTCCTGTGTCATGCTGCACAGCTGCAGGCC \\
\hline Y853-15 & GAGGAGTTCGTCGAGGCAGCTGGCCTCTGCGGCGAGTACCTGTAC \\
\hline Y853-16 & TTGTGTGCGGATGTTCTGGAGGATGAAGTACAGGTACTCGCCGCA \\
\hline Y853-17 & CCAGAACATCCGCACACAAGGTTACTCCTTTTTTAATGACGCTGA \\
\hline Y853-18 & TGATGGTGGCCTTGCTTTCTTCAGCGTCATTAAAAAAGGAGTAAC \\
\hline Y853-19 & GAAAGCAAGGCCACCATCAAAGACTATGCTGATTCCAACTGCTTG \\
\hline Y853-20 & TGACTTTTGATGCCACTTGTTTTCAAGCAGTTGGAATCAGCATAG \\
\hline Y853-21 & 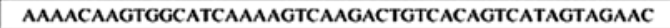 \\
\hline Y853-22 & CATAGATGAGAACTTTGGAGGCTTGTTCTACTATGACTGTGACAGTCT \\
\hline Y853-23 & AAGCCTCCAAAGTTCTCATCTATGGGAATTTGTACGAGACCTGCT \\
\hline Y853-24 & CCACAGTTTTCTTCAGGAGATAGAAGCAGGTCTCGTACAAATTCC \\
\hline Y853-25 & TCTATCTCCTGAAGAAAACTGTGGCATTCTGGAATGGGAAGATAGGG \\
\hline Y853-26 & 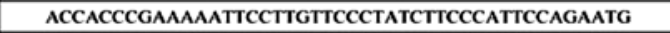 \\
\hline Y853-27 & ACAAGGAATTTTTCGGGTGGTTAAATCGGAAGCCCTGGCAAAGAT \\
\hline Y853-28 & TGTCATTTTTCTTCCTTTGTCCCCACATCTTTGCCAGGGCTTCCG \\
\hline Y853-29 & GGGACAAAGGAAGAAAAATGACAGAATGACATATGAAAAGTTGAGCAG \\
\hline Y853-30 & TGTTTTATAGTAGTATCTCAGGGCTCTGCTCAACTTTTCATATGTCATTC \\
\hline Y853-31 & AGCCCTGAGATACTACTATAAAACAGGAATTTTGGAGCGGGTTGA \\
\hline Y853-32 & TCCAAATTTGTACACTAACCTTCGGTCAACCCGCTCCAAAATTCC \\
\hline Y853-33 & CGAAGGTTAGTGTACAAATTTGGAAAAAATGCACACGGGTGGCAG \\
\hline Y853-34 & ССTCGCCCTTGCTCACTAGCTTGTCTTCCTGCCACCCGTGTGCAT \\
\hline Y853-35 & AGTGAGCAAGGGCGAGGAGCTGTTCACCGGGGTGGTGCCCATCCT \\
\hline Y853-36 & GCTCGACCAGGATGGGCACCACCC \\
\hline Y853R & CTATGGAATTCitacttgtacagetcgtocatgecgagagtg \\
\hline Y853-1 & GATAGGGATCCGCCACCATGCCA \\
\hline Y853-2 & ACATTACCCTGTGGGAGTGAGGCAGAGATGGCATGGTGGCGGATC \\
\hline Y853-3 & СТСАСТСССАСАGGGTAATGTTGGACTCGGTGACACACAGCACCT \\
\hline Y853-4 & GATCGCAGAAGGATGCATTAGGCAGGAAGGTGCTGTGTGTCACCG \\
\hline Y853-5 & СCTAATGCATCCTTCTGCGATCCCCTGATGTCGTGGACTGATCTG \\
\hline Y853-6 & AGGGTAGTACTCTTCATTGCTGAACAGATCAGTCCACGACATCAG \\
\hline Y853-7 & TCAGCAATGAAGAGTACTACCCTGCCTTTGAGCATCAGACAGCCT \\
\hline Y853-8 & TGGACTGATGTCCAGTATGAGTCACAGGCTGTCTGATGCTCAAAG \\
\hline Y853-9 & АСТСАТАСТGGАСАТСАGТССАСССТGААТАСТGGАСТААGСGСС \\
\hline
\end{tabular}

Figure 1. Oligo sequences.

transferred to competent cells, colonies were selected, and mini preparation plasmids were identified to select positive clones. Four single colonies were selected and placed in tubes containing $5 \mathrm{ml}$ (containing $50 \mu \mathrm{g} / \mathrm{ml}$ ampicillin) LB medium. The above tubes were placed in a shaker to cultivate at $37^{\circ} \mathrm{C}$ and $250 \mathrm{rpm}$ for $16 \mathrm{~h}$. Plasmids were extracted with plasmid minipreparation kit from cultured bacterial liquid and enzyme digestion identification was performed for the extracted plasmids.

Bacterial liquid $(200 \mu \mathrm{l})$ corresponding to positive clone was sequenced and the rest was stored with glycerin. Sequencing results were compared with target genes. After ensuring that they were corrected and LB medium was inoculated with stored glycerin bacterial liquid, a large amount of plasmids were extracted for sufficient recombinant plasmid.

Cell culture. Human ovarian carcinoma SKOV3 cells were subcultured at $37^{\circ} \mathrm{C}, 5 \% \mathrm{CO}_{2}$, in saturated humidity constant temperature incubator by applying routine RPMI-1640 medium (containing penicillin and streptomycin) added with $10 \%$ fetal calf serum.
Gene transfection and grouping. Eukaryotic expression vectors with ELF5 gene were transfected in vitro into human ovarian carcinoma SKOV3 cells (recombinant plasmid group) by lipofectin method. The operation was performed according to the instructions of liptapfector lipofectin transfection kit. Stably transfected cells were screened to implement amplification and culture with pcDNA3.1-EGFP empty vector plasmid (empty plasmid group) and untransfected human ovarian carcinoma SKOV3 cells (blank control group) as control. After transfection, screening and passage were conducted by applying selective medium containing neomycin (G418).

Detection of the expression of ELF5 protein by western blot analysis. Three groups of cells in logarithmic growth phase were harvested in $200 \mu \mathrm{l}$ cell lysis buffer on ice. The concentration of protein was measured by bicinchoninic acid (BCA) method and $10 \%$ sodium dodecyl sulfate-polyacrylamide gel electrophoresis (SDS-PAGE), respectively. Then, electrotransferred onto nitrocellulose membrane, sealed with 5\% skim milk powder for $60 \mathrm{~min}$, and ELF5 primary antibody (rabbit anti-human) (dilution, 1:1,000; cat. no. AM254515) was added at $4^{\circ} \mathrm{C}$ overnight. After 2 -h reaction with goat anti-rabbit secondary antibody (1:10,000; cat. no. MAB4310) marked with horseradish peroxidase at room temperature. Strengthened electrochemical luminescence (ECL) reagent was added for exposure and development with highly sensitive X-ray film.

Detection of proliferation capacity of ovarian carcinoma SKOV3 cells by MTT method. Three groups of cells were inoculated on 96-well plates at $1.5 \times 10^{5} /$ well and $20 \mu 1 \mathrm{MTT}$ working solution was added after cultivation for $1,2,3,4$, 5 and 6 days. After cells were cultivated in $\mathrm{CO}_{2}$ incubator at $37^{\circ} \mathrm{C}$ for $4 \mathrm{~h}$, dimethyl sulfoxide was added to terminate the reaction. Absorbance (A) values of all wells at $490 \mathrm{~nm}$ were determined on enzyme-linked immunoassay and the cell growth curve was drawn.

Detection of invasive capacity of ovarian carcinoma SKOV3 cells by in vitro invasion assay. Transwell chamber in vitro invasion assay was applied. Membrane was prepared with Matrigel between upper and lower chambers. Single cell suspension of ovarian carcinoma SKOV3 cells was inoculated at $200 \mu \mathrm{l} /$ well (containing about $10^{5}$ cells). After cultivating at $37^{\circ} \mathrm{C}$ and $5 \% \mathrm{CO}_{2}$ for $12 \mathrm{~h}$, the cells and Matrigel on membrane were wiped off and fixed and H\&E stained. The number of cells was calculated under a microscope. Three wells were set for each group of cells and the experiment was repeated 3 times.

Detection of cell cycle of ovarian carcinoma SKOV3 cells by flow cytometry. Ovarian carcinoma SKOV3 cells that stably expressed ELF5 protein were selected. The cells were digested with $0.25 \%$ pancreatin, routinely washed with normal saline, centrifuged at $1.200 \mathrm{x} \mathrm{g}$ at $4^{\circ} \mathrm{C}$ for $8 \mathrm{~min}$ and fixed with $70 \%$ ethyl alcohol overnight. Single-cell suspension was prepared by adding $100 \mu \mathrm{l}$ phosphate-buffered saline (PBS) and the cell cycle was analyzed by flow cytometry.

Detection of apoptosis rate of ovarian carcinoma SKOV3 cells by flow cytometry. Ovarian carcinoma SKOV3 cells 
that stably expressed ELF5 protein after transfection were selected. The cells were digested with $0.25 \%$ pancreatin, routinely washed with normal saline, centrifuged $1.200 \mathrm{x} \mathrm{g}$ at $4^{\circ} \mathrm{C}$ for $8 \mathrm{~min}$ and fixed with $70 \%$ ethyl alcohol overnight. Single-cell suspension was prepared by adding $100 \mu$ PBS. Operation was performed according to the instructions of Annexin V-PI cell apoptosis detection kit. The cell apoptotic rate was analyzed by flow cytometry.

Statistical analysis. SPSS 13.0 statistical software (SPSS, Inc., Chicago, IL, USA) was used for analysis. Comparison of rates among groups was tested by $\chi^{2}$ test and Fisher's exact probability calculation method. Measurement data were expressed as mean $\pm \mathrm{SD}$; differences among groups were analyzed by variance, comparison of data among groups was tested by q-test; and $\mathrm{P}<0.05$ was considered to indicate a statistically significant difference.

\section{Results}

Expression of ELF5 mRNA in different ovarian tissues. The rate of positive expression and the level of expression of ELF5 mRNA in epithelial ovarian carcinoma and borderline ovarian epithelial tumor tissues were significantly lower $(\mathrm{P}<0.05)$ than those in benign ovarian epithelial tumor and normal ovarian tissues. The rate of positive expression and the level of expression of ELF5 mRNA in epithelial ovarian carcinoma tissues were significantly lower $(\mathrm{P}<0.05)$ than those in borderline ovarian epithelial tumor. The rate of positive expression and the level of expression in benign ovarian epithelial tumor and normal ovarian tissues had no significant differences (Fig. 2 and Table I).

Expression of ELF5 mRNA in epithelial ovarian carcinoma tissues at different clinicopathological indexes. The rate of positive expression and the level of expression of ELF5 mRNA in early phase (phase I and II) in epithelial ovarian carcinoma tissues were significantly higher than $(\mathrm{P}<0.05)$ those in late phase (phase III and IV). The positive expression rate and expression level of ELF5 mRNA in epithelial ovarian carcinoma tissues with lymph node metastases were significantly lower $(\mathrm{P}<0.05)$ than those in epithelial ovarian carcinoma tissues without lymph node metastases. The rate of positive expression and the level of expression of ELF5 mRNA showed no correlation with age, pathological grading, pathological types and ascites formation (Table II and Fig. 3).

Successfully constructed pcDNA3.1-ELF5+EGFP eukaryotic expression vector. We utilized continuous PCR method to obtained complete gene sequence fragments of ELF5+EGFP, cloned target gene ELF5+EGFP into vector pcDNA3.1. After enzyme digestion, it showed significant bands at the position of $1,518 \mathrm{bp}$, which was in line with the size of fragment expected to be amplified (Fig. 4A).

The results of DNA sequence analysis showed that the sequence of target gene was identical to that of the gene sequence in GeneBank. The insert direction of target gene was correct and the reading frame remained unchanged, which proved that recombinant plasmid pcDNA3.1-ELF5+EGFP was constructed successfully (Fig. 4B).
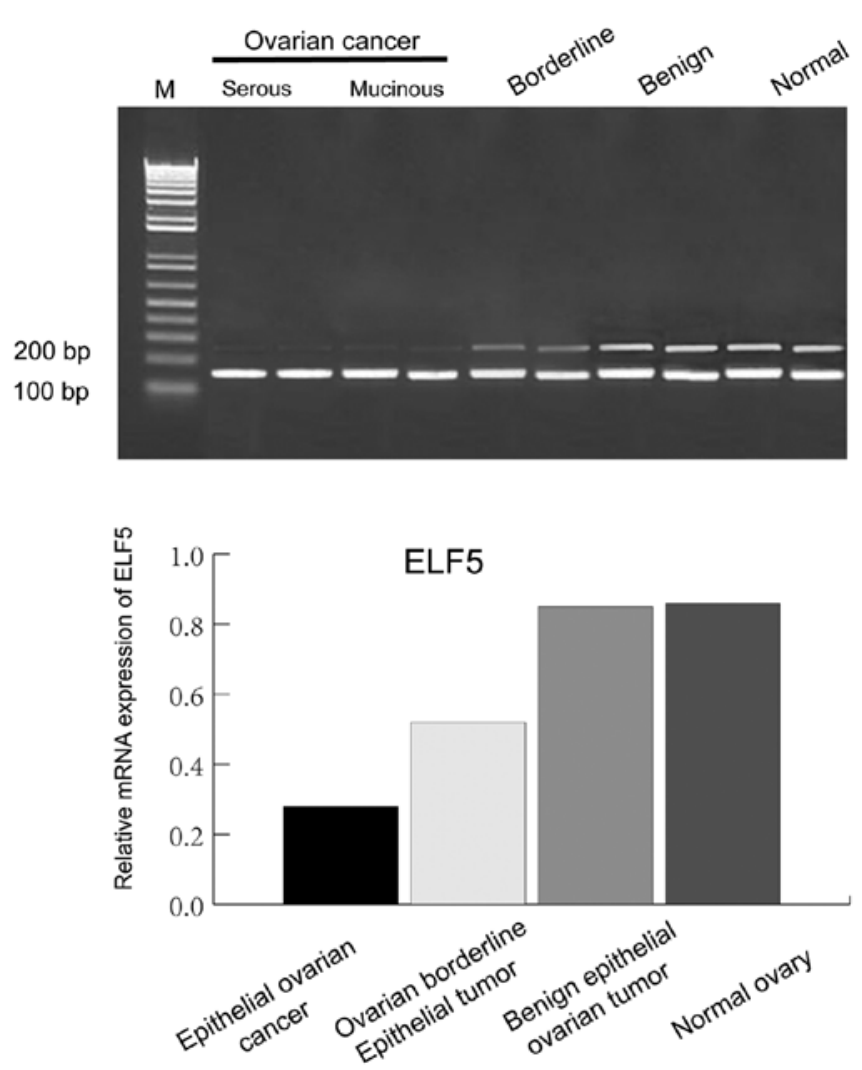

Figure 2. mRNA expression of ELF5 in different ovarian tissues ELF5, E74-like factor 5.

Table I. ELF5 mRNA expression in various ovarian tissues.

\begin{tabular}{lccc}
\hline & $\begin{array}{c}\text { Total } \\
\text { cases }\end{array}$ & $\begin{array}{c}\text { Positive } \\
\text { cases }\end{array}$ & $\begin{array}{c}\text { Percentage } \\
(\%)\end{array}$ \\
\hline $\begin{array}{l}\text { Epithelial } \\
\text { ovarian cancer } \\
\begin{array}{l}\text { Ovarian borderline } \\
\text { epithelial tumor }\end{array}\end{array}$ & 49 & 9 & 18.4 \\
$\begin{array}{l}\text { Benign epithelial } \\
\text { ovarian tumor }\end{array}$ & 31 & 21 & 36.8 \\
Normal ovary & 40 & 29 & 67.7 \\
\hline
\end{tabular}

Changes in the expression of ELF5 protein in ovarian carcinoma SKOV3 cells after the transfection of ELF5 gene. The western blot results of the detection of the expression of ELF5 in recombinant plasmid group was high, while the expression of ELF5 was not detected in empty plasmid group or blank control group (Fig. 5).

Changes in the reproductive capacity of ovarian carcinoma SKOV3 cells after the transfection of ELF5 gene. The results of the detection of MTT method showed that after being cultivated for 1, 2, 3, 4, 5 and 6 days, the A values of recombinant plasmid group were $0.337 \pm 0.002,0.413 \pm 0.012,0.522 \pm 0.007$, $0.761 \pm 0.002,0.787 \pm 0.021$ and $0.821 \pm 0.019$, respectively. These decreased obviously compared with blank control group and empty plasmid group at each time-point $(\mathrm{P}<0.05)$ while the 


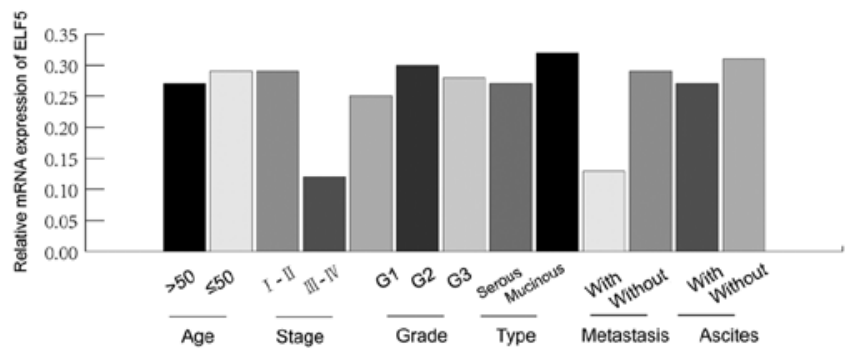

Figure 3. mRNA expression of ELF5 in ovarian cancer at different clinical stages. ELF5, E74-like factor 5.

Table II. ELF5 mRNA expression in epithelial ovarian cancer tissues of clinicopathological indexes.

\begin{tabular}{lcccc}
\hline Parameters & Total & Positive Percentage (\%) & P-value \\
\hline Age (years) & & & & \\
$>50$ & 27 & 5 & 18.5 & 00.817 \\
$\leq 50$ & 22 & 4 & 18.2 & \\
Pathological staging & & & & \\
I-II & 23 & 6 & 26.1 & 0.015 \\
III-IV & 26 & 3 & 11.5 & \\
Pathological grading & & & & \\
G1 & 20 & 4 & 20.0 & 0.797 \\
G2 & 17 & 3 & 17.6 & \\
G3 & 12 & 2 & 16.7 & \\
Pathological type & & & & \\
Serous & 32 & 6 & 18.8 & 0.812 \\
cystadenocarcinoma & & & & \\
Mucinous & 17 & 3 & 17.6 & \\
cystadenocarcinoma & & & & \\
Lymphatic metastasis & & & & \\
With & 21 & 2 & 9.5 & 0.019 \\
Without & 28 & 7 & 25.0 & \\
Ascites & & & & \\
With & 16 & 3 & 18.8 & \\
Without & $\mathbf{3 3}$ & $\mathbf{6}$ & 18.2 & \\
\hline
\end{tabular}

ELF5, E74-like factor 5. Bold indicates that from a total of 49 patients with ovarian cancer, 6 out of 33 patients with no ascites showed ELF5 positive expression.

comparison of blank control group and empty plasmid group showed the differences were not statistically significant (Fig. 6).

Changes in the invasive capacity of ovarian carcinoma SKOV3 cells after the transfection of ELF5 gene. Transwell chamber in vitro invasion assay showed that the number of cells permeating in recombinant plasmid group was $92.1 \pm 2.7$, compared with empty plasmid group (149.6 \pm 4.6$)$ and blank control group $(147.4 \pm 5.3)$, and the differences were statistically significant $(\mathrm{P}<0.05)$.

Changes in the cell cycle of ovarian carcinoma SKOV3 cells after the transfection of ELF5 gene. Flow cytometry detection showed that $67.03 \%$ of cells in recombinant plasmid group was blocked in $\mathrm{G}_{0} / \mathrm{G}_{1}$ phase, compared with empty plasmid group (37.17\%) and blank control group (38.24\%), and the differences were statistically significant $(\mathrm{P}<0.05)$ (Table III).

Changes in the apoptotic rate of ovarian carcinoma SKOV3 cells after the transfection of ELF5 gene. Flow cytometry showed that the apoptotic rate of recombinant plasmid group was $31.4 \pm 1.9 \%$, compared with that of empty plasmid group $(9.1 \pm 2.2 \%)$ and blank control group $(8.7 \pm 1.5 \%)$, and the differences were statistically significant $(\mathrm{P}<0.05)$.

\section{Discussion}

Ets family members have very important regulating effects on normal physiological activities, including cell development, differentiation, proliferation and apoptosis (10). As a member of Ets family, ELF5 locates in 13-15 region of short arm of chromosome 11, generating loss of heterozygosity in cancer. ELF5 contains two identifiable domains, one is the sequence motif that is contained by all ETS transcription factors and can combine with TTCC core sequence, the other is the point domain that takes part in the interaction between proteins (6). ELF5 is expressed in hair follicle, epithelial exocrine glands, placental trophoblastic cells, kidney, mammary gland and other organs (11-15).

Studies on ELF5 are mainly focused on mammary gland cells and breast carcinoma. In the breast tissues, ELF5 is secreted by the mammary duct precursor cells and ELF5 is an important regulatory factor for development of mammary acinar cells. On one hand, it can decide the fate of acinar cells (16), and on the other hand, it can affect embryogenesis and hyperplasia of breast acinus through regulating breast lactation acinus structure during pregnancy. Studies of Chakrabarti et al (17) showed that during the process of normal mammogenesis, the loss of ELF5 could cause the increase of mammary adult stem cells, thus to increase the risk of forming breast carcinoma. It has been shown that ELF5 was a potential tumor-inhibiting factor and played a role of tumor suppressor gene during the process of occurrence and development of breast carcinoma. Due to the expression loss of ELF5 in human breast carcinoma tissues and cell lines, regulating the transcriptional level of ELF5 may provide a new method for the treatment of breast carcinoma (18-20).

Inspired by above studies, we considered the following: How does ELF5 express in epithelial ovarian carcinoma tissues, and does ELF5 gene have effects on biological behavior of human ovarian carcinoma SKOV3 cells?

This study found that the positive expression rate and expression level of ELF5 mRNA in epithelial ovarian carcinoma and borderline ovarian epithelial tumor tissues were significantly lower than those in benign ovarian epithelial tumor and normal ovarian tissues. Our study also showed that the positive expression rate and expression level of ELF5 mRNA in epithelial ovarian carcinoma tissues showed no correlation with its pathological grading, pathological types and ascites formation. The positive expression rate and expression level of ELF5 mRNA in epithelial ovarian carcinoma tissues in patients at early clinical stage without lymph node metastasis 


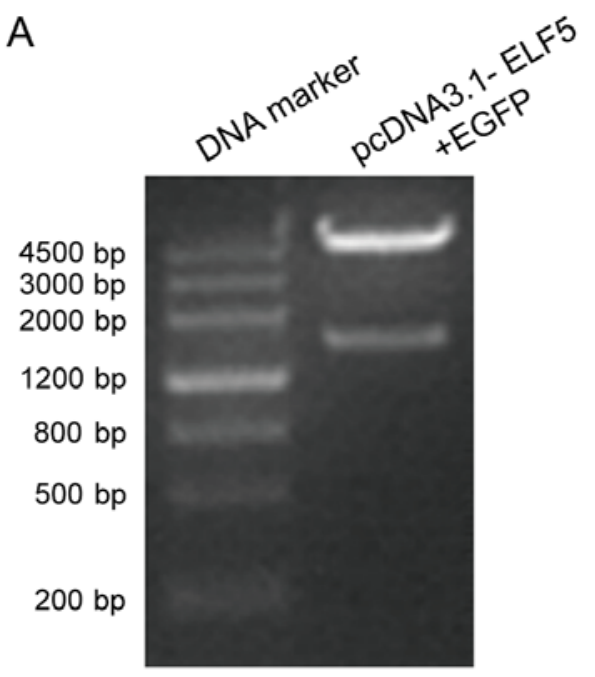

B

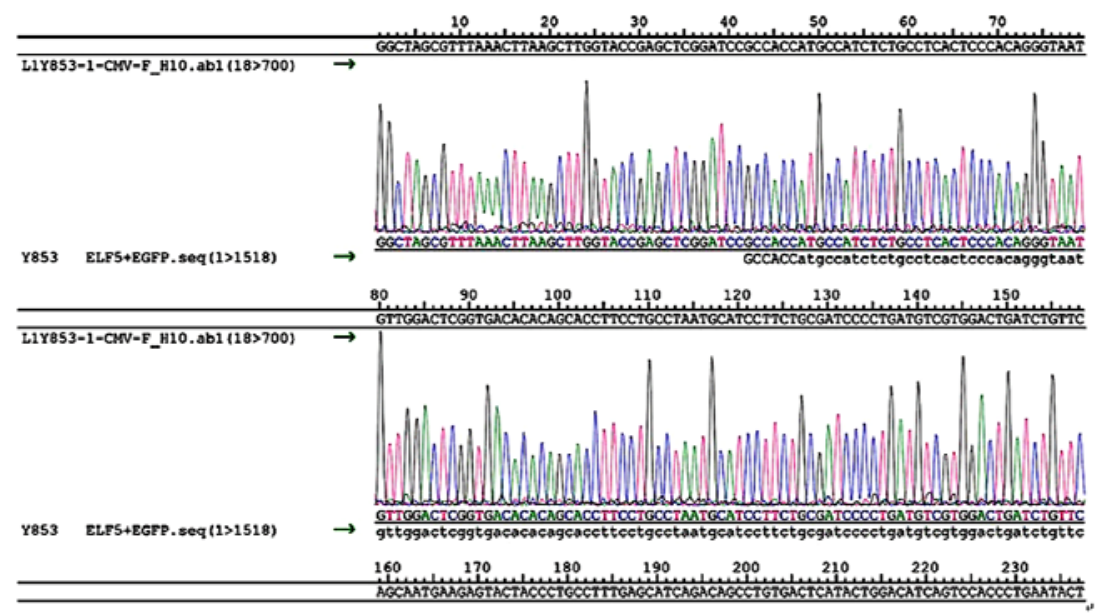

Figure 4. Construction of pcDNA3.1-ELF5+EGFP eukaryotic expression vector. (A) pcDNA3.1-ELF5+EGFP macrorestriction map; (B) DNA sequence analysis. ELF5, E74-like factor 5.

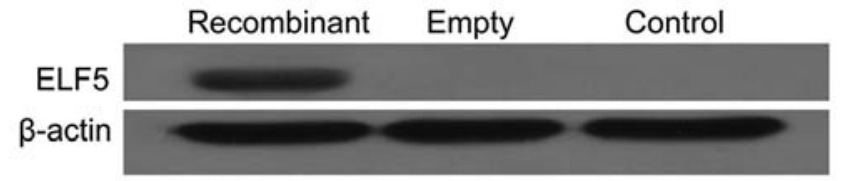

Figure 5. Protein expression of ELF5 in SKOV3 cells for different groups. ELF5, E74-like factor 5.

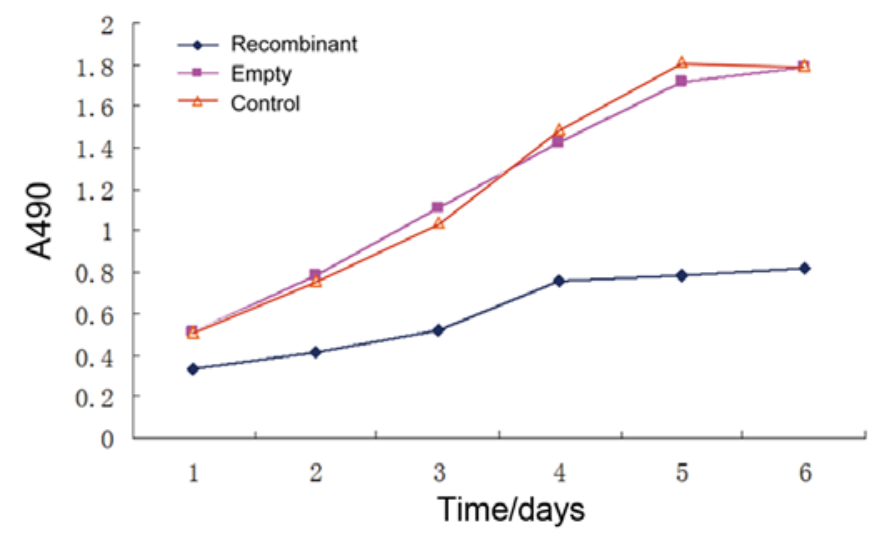

Figure 6. Proliferation of SKOV3 cells after transfection with pcDNA3.1-ELF5+EGFP. ELF5, E74-like factor 5.

were apparently higher than those in patients at late clinical stage with lymph node metastasis. Thus, we could further speculated that the ELF5 gene, not only as a tumor suppressor gene, but also an inhibiting gene for tumor metastasis, plays an important role in the process of inhibiting infiltration and metastasis for ovarian carcinoma cells, and the infiltration and metastasis is an important index for judging prognosis of patients with epithelial ovarian carcinoma.

In order to further implement deep and extensive studies on ELF5, we successfully constructed recombinant plasmid pcDNA3.1-ELF5+EGFP, transfected recombinant plasmid pcDNA3.1-ELF5+EGFP into human ovarian carcinoma SKOV3 cells and conducted screening. The cultivation and
Table III. Changes of ovarian cancer SKOV3 cell cycle after transfection by ELF5 gene (mean \pm SD, \%).

\begin{tabular}{lccc}
\hline & Stage $\mathrm{G}_{0} / \mathrm{G}_{1}$ & Stage $\mathrm{S}$ & Stage $/ \mathrm{M}$ \\
\hline $\begin{array}{l}\text { Recombinant } \\
\text { plasmid }\end{array}$ & $67.03 \pm 0.14$ & $18.21 \pm 1.02$ & $14.37 \pm 0.13$ \\
Empty plasmid & $39.23 \pm 1.21$ & $39.41 \pm 0.11$ & $21.62 \pm 0.33$ \\
Control & $40.22 \pm 0.38$ & $40.28 \pm 0.31$ & $19.22 \pm 0.15$ \\
\hline
\end{tabular}

ELF5, E74-like factor 5.

identification for positive clone showed successful transfection of recombinant plasmid pcDNA3.1-ELF5+EGFP at the protein level, and then studied the effects of ELF5 gene after transfection on in vitro biological behavior of ovarian carcinoma SKOV 3 cells. The cell growth curve experiment showed that ovarian carcinoma SKOV3 cells grew slower after the transfection of ELF5 gene, suggesting that the ELF5 gene delayed the proliferation of ovarian carcinoma SKOV3 cells. The analysis of flow cytometry showed, the high expression of ELF5 gene could delay cells in phase $G_{0} / G_{1}$ from entering into phase $S$ and phase $\mathrm{G}_{2} / \mathrm{M}$; and thus, it could be speculated that ELF5 gene could inhibit the proliferation of ovarian carcinoma SKOV3 cells through intervening in the cell cycle. The apoptosis rate of ovarian carcinoma SKOV3 cells after the transfection of ELF5 gene increased significantly and showed that ELF5 gene could promote apoptosis of ovarian carcinoma SKOV3 cells.

The in vitro invasive capacity is important to measure tumor metastasis potential. Transwell chamber in vitro invasion assay showed that the invasive capacity of ovarian carcinoma SKOV3 cells after the transfection of ELF5 gene decreased significantly. This showed that the ELF5 gene had obvious inhibiting effects on invasive capacity to host and motor ability of ovarian carcinoma SKOV3 cells. Our experiments proved that on one hand, ELF5 mRNA had low 
expression in epithelial ovarian carcinoma tissues and its expression loss at different levels was related to the occurrence and development of epithelial ovarian carcinoma. ELF5 gene disturbed the cell cycle of human ovarian carcinoma SKOV3 cells, promoting apoptosis of human ovarian carcinoma SKOV3 cells and inhibited its growth and invasive capacity. The results of our study provide some experimental foundation for conducting gene treatment of ovarian carcinoma, but the following problems are still not cleared: i) What is the mechanism of the expression loss of ELF5 mRNA for causing the occurrence of ovarian carcinoma. The expression of ELF5 mRNA in ovarian carcinoma is generally low. Moreover, it shows abnormal expression in borderline ovarian epithelial tumor tissues. The effects on the occurrence and development of epithelial ovarian carcinoma and whether it can serve as a new therapeutic target of epithelial ovarian carcinoma are worth further research. ii) The specific mechanism of ELF5 gene that affects the biological behavior of ovarian carcinoma SKOV3 cells is not clear, and thus ELF5 gene therapy needs further investigation to improve the survival rate of ovarian carcinoma.

\section{References}

1. Jemal A, Bray F, Center MM, Ferlay J, Ward E and Forman D: Global cancer statistics. CA Cancer J Clin 61: 69-90, 2011.

2. Lee JY, Kim HS, Suh DH, Kim MK, Chung HH and Song YS: Ovarian cancer biomarker discovery based on genomic approaches. J Cancer Prev 18: 298-312, 2013.

3. Suh DH, Kim MK, Kim HS, Chung HH and Song YS: Epigenetic therapies as a promising strategy for overcoming chemoresistance in epithelial ovarian cancer. J Cancer Prev 18: 227-234, 2013.

4. Zheng H, Liu JY, Song FJ and Chen KX: Advances in circulating microRNAs as diagnostic and prognostic markers for ovarian cancer. Cancer Biol Med 10: 123-130, 2013.

5. Lin JY, Qin JB, Li XY, Dong P and Yin BD: Diagnostic value of human epididymis protein 4 compared with mesothelin for ovarian cancer: a systematic review and meta-analysis. Asian Pac J Cancer Prev 13: 5427-5432, 2012.

6. Zhou J, Ng AY, Tymms MJ, Jermiin LS, Seth AK, Thomas RS and Kola I: A novel transcription factor, ELF5, belongs to the ELF subfamily of ETS genes and maps to human chromosome 11p13-15, a region subject to $\mathrm{LOH}$ and rearrangement in human carcinoma cell lines. Oncogene 17: 2719-2732, 1998.
7. Choi YS and Sinha S: Determination of the consensus DNA-binding sequence and a transcriptional activation domain for ESE-2. Biochem J 398: 497-507, 2006.

8. Prat J; FIGO Committee on Gynecologic Oncology: Staging classification for cancer of the ovary, fallopian tube, and peritoneum. Int J Gynaecol Obstet 124: 1-5, 2014.

9. He J, Pan Y, Hu J, Albarracin C, Wu Y and Dai JL: Profile of Ets gene expression in human breast carcinoma. Cancer Biol Ther 6: 76-82, 2007.

10. Lee HJ and Ormandy CJ: Elf5, hormones and cell fate. Trends Endocrinol Metab 23: 292-298, 2012.

11. Lapinskas EJ, Palmer J, Ricardo S, Hertzog PJ, Hammacher A and Pritchard MA: A major site of expression of the ets transcription factor Elf5 is epithelia of exocrine glands. Histochem Cell Biol 122: 521-526, 2004.

12. Hemberger M, Udayashankar R, Tesar P, Moore H and Burton GJ: ELF5-enforced transcriptional networks define an epigenetically regulated trophoblast stem cell compartment in the human placenta. Hum Mol Genet 19: 2456-2467, 2010.

13. Lee HJ, Gallego-Ortega D, Ledger A, Schramek D, Joshi P, Szwarc MM, Cho C, Lydon JP, Khokha R, Penninger JM, et al: Progesterone drives mammary secretory differentiation via RankL-mediated induction of Elf5 in luminal progenitor cells. Development 140: 1397-1401, 2013.

14. Lapinskas EJ, Svobodova S, Davis ID, Cebon J, Hertzog PJ and Pritchard MA: The Ets transcription factor ELF5 functions as a tumor suppressor in the kidney. Twin Res Hum Genet 14: 316-322, 2011.

15. Pearton DJ, Smith CS, Redgate E, van Leeuwen J, Donnison M and Pfeffer PL: Elf5 counteracts precocious trophoblast differentiation by maintaining Sox 2 and 3 and inhibiting Handl expression. Dev Biol 392: 344-357, 2014.

16. Lee HJ, Hinshelwood RA, Bouras T, Gallego-Ortega D, Valdés-Mora F, Blazek K, Visvader JE, Clark SJ and Ormandy CJ: Lineage specific methylation of the Elf5 promoter in mammary epithelial cells. Stem Cells 29: 1611-1619, 2011.

17. Chakrabarti R, Wei Y, Romano RA, DeCoste C, Kang Y and Sinha S: Elf5 regulates mammary gland stem/progenitor cell fate by influencing notch signaling. Stem Cells 30: 1496-1508, 2012.

18. Chakrabarti R, Hwang J, Andres Blanco M, Wei Y, Lukačišin M, Romano RA, Smalley K, Liu S, Yang Q, Ibrahim T, et al: Elf5 inhibits the epithelial-mesenchymal transition in mammary gland development and breast cancer metastasis by transcriptionally repressing Snail2. Nat Cell Biol 14: 1212-1222, 2012

19. Kalyuga M, Gallego-Ortega D, Lee HJ, Roden DL, Cowley MJ, Caldon CE, Stone A, Allerdice SL, Valdes-Mora F, Launchbury R, et al: ELF5 suppresses estrogen sensitivity and underpins the acquisition of antiestrogen resistance in luminal breast cancer. PLoS Biol 10: e1001461, 2012.

20. Frend HT and Watson CJ: Elf5 - breast cancer's little helper. Breast Cancer Res 15: 307, 2013 